\title{
Evaluation of microwave and ultrasound extraction procedures for arsenic speciation in bivalve mollusks by liquid chromatography-inductively coupled plasma-mass spectrometry
}

\author{
Clarissa M.M. Santos a , Matheus A.G. Nunes a ${ }^{\text {a Isa S. Barbosa }}{ }^{\text {b }}$, Gabriel L. Santos ${ }^{\text {b }}$, \\ Marlene C. Peso-Aguiar ${ }^{c}$, Maria G.A. Korn ${ }^{\text {b }}$, Erico M.M. Flores ${ }^{a}$, Valderi L. Dressler ${ }^{\text {a,* }}$ \\ a Departamento de Química, Universidade Federal de Santa Maria, Santa Maria, RS, Brazil \\ ' Instituto de Química, Universidade Federal da Bahia, Salvador, BA, Brazil

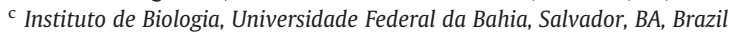

\section{A R T I C L E I N F O}

\section{Article history:}

Received 31 October 2012

Accepted 10 May 2013

Available online 5 June 2013

Keywords:

Arsenic

Speciation analysis

LC-ICP-MS

Mollusks

\begin{abstract}
A B S T R A C T
Liquid chromatography-inductively coupled plasma-mass spectrometry (LC-ICP-MS) was used for arsenic speciation analysis in tissues of bivalve mollusks (Anomalocardia brasiliana sp. and Macoma constricta sp.). Microwave and ultrasound radiation, combined with different extraction conditions (solvent, sample amount, time, and temperature), were evaluated for As-species extraction from the mollusks' tissues. Accuracy, extraction efficiency, and the stability of As species were evaluated by analyzing certified reference materials (DORM-2, dogfish muscle; BCR-627, tuna fish tissue; and SRM 1566b, oyster tissue) and analyte recovery tests. The best conditions were found to be microwave-assisted extraction using $200 \mathrm{mg}$ of samples and water at $80{ }^{\circ} \mathrm{C}$ for $6 \mathrm{~min}$. The agreement of As-species concentration in samples ranged from 97\% to 102\%. Arsenobetaine (AsB) was the main species present in bivalve mollusk tissues, while monomethylarsonic acid (MMA) and arsenate $(\mathrm{As}(\mathrm{V}))$ were below the limit of quantification $\left(0.001\right.$ and $0.003 \mu \mathrm{g} \mathrm{g}{ }^{-1}$, respectively). Two unidentified As species also were detected and quantified. The sum of the As-species concentration was in agreement (90 to $104 \%$ ), with the total As content determined by ICP-MS after sample digestion.
\end{abstract}

(c) 2013 Elsevier B.V. All rights reserved.

\section{Introduction}

Marine organisms, such as bivalve mollusks, are widely consumed by humans. The consumption of bivalve mollusks is common in all coastal regions of Brazil due to the abundance of natural resources of the aquatic ecosystem. Todos os Santos Bay (Bahia, Brazil) is an important fishing community, the main activity of which is collecting mollusks in the nearby mangrove [1]. However, bivalve mollusks are among the biggest accumulators of contaminants from the environment, and their consumption is associated with human intoxication [2].

One of the main elements that mollusks can bioaccumulate is arsenic, mainly organic arsenic. Inorganic arsenic (i-As) can be bioconverted to methylated species such as monomethylarsonic acid (MMA) or arsenobetaine (AsB) [3]. The biotransformation rate depends on the intake of As and the transformation mechanisms in animals. The correlation between the total element concentration and the metabolized fraction is not completely known $[1,3]$.

The quantification of total As concentration in seafood already is performed routinely. However, the toxic and biological effects of As

\footnotetext{
* Corresponding author. Tel.: + 555532209445.

E-mail address: vdressler@gmail.com (V.L. Dressler).
}

cannot be associated only with total arsenic concentration. The toxicities of As species differ mainly in terms of their oxidation states and whether they are present in inorganic or organic forms. For example, inorganic As is considered carcinogenic [4], while organic As - such as $\mathrm{AsB}$, arsenocoline (AsC), and several arsenosugars - are considered nontoxic.

The predominant As species in bivalve mollusks is AsB, the concentration of which ranges from 1 to $100 \mu \mathrm{g} \mathrm{g}^{-1}$ [5]. Minor species - such as MMA, dimethylarsenic acid (DMA), and tetramethylarsonium ion (TMA) - also have been found [6,7]. Therefore, the total concentration of As species in seafood should be determined in order to effectively evaluate the toxicity of the element and potential effects on humans.

Several studies have focused on As speciation analysis [6-11]. Usually, a combination of analytical techniques is necessary to achieve sufficient selectivity and sensitivity for speciation analysis. Liquid chromatography (LC) with inductively coupled plasma mass spectrometry (ICP-MS) has been used most often. This technique allows good separation of As species, in addition to the selective detection of species present in low concentrations.

The inclusion of a hydride generation system after the chromatographic column can improve the limit of detection (LOD) and can reduce interferences $[8,12-14]$. However, arsenic speciation analysis is still challenging because the integrity of the As species must be 
maintained during all steps of the analysis, and sample storage and sample preparation are most critical steps. Established methods to extract arsenic species from solid samples are still not available, and certified reference materials (CRMs) with certified mass fractions values of As species are scarce. So, the accuracy of the method is not easily accessed $[8,15]$. The difficulty of $\mathrm{i}$-As speciation analysis in seafood has been demonstrated recently $[8,15]$. The authors of those studies highlighted that there are strong discrepancies among the results found by different laboratories [15].

As stated before, sample preparation is critical in speciation analysis, mainly for solid matrices. Diluted acids, water, methanol, and a methanol-water mixture are the most common solvents used for As-species extraction from biological samples [15-18]. To accelerate the As-species extraction, mechanical stirring and Soxhlet extraction are usually employed [19]. More recently, ultrasound (US) extraction [20-23], microwave-assisted extraction (MAE) [11,24-30], supercritical fluid extraction, and pressurized liquid extraction [31,32] have been evaluated in order to reduce the extraction time and volume of extractant. The extraction efficiency depends on the sample matrix, species to be extracted, type of solvent, extraction time, and temperature. However, in general, there is no universal procedure for species extraction in speciation analysis and it is necessary to investigate the extraction conditions for each sample matrix.

Most of the As species present in biological tissues are soluble in water and can be extracted with water alone or with a mixture of water and methanol. Orthophosphoric acid and trifluoroacetic acid have been used to improve extraction efficiency. Extraction of As species from fish tissue also has been carried out by means of enzymes $[22,33]$.

In the present study, the application of MAE and US combined with different solvents were investigated for As-species extraction from edible tissues of bivalve mollusks. Arsenic species were separated using anion-exchange chromatography and detected using ICP-MS. The method was applied for As speciation analysis in samples of bivalve mollusks collected in an area that is highly impacted by human activities.

\section{Experimental}

\subsection{Instrumentation}

For As detection, an inductively coupled plasma-mass spectrometer (Elan DRC II, PerkinElmer Sciex, Thornhill, Canada) equipped with a concentric nebulizer (Meinhard Associates, Santa Ana, CA, USA), a cyclonic spray chamber (Glass Expansion, Inc., West Melbourne, Victoria, Australia), and a quartz torch with a quartz injector tube (2 $\mathrm{mm}$ i.d.) was used. The nebulizer gas flow rate, ion lens voltage, and torch alignment were adjusted following the manufacturers' instructions, using conventional nebulization. Single-ion monitoring for $\mathrm{m} / \mathrm{z} 75$ was used to collect the As signal. The LC system consisted of a quaternary pump (Series 200, PerkinElmer) equipped with a Rheodyne six-port injector valve (200 $\mu \mathrm{L}$ sample loop) and an anion-exchange separation column (Hamilton, PRP-X100, $250 \mathrm{~cm}$ length and $4.1 \mathrm{~mm}$ i.d.). The column outlet was connected to the pneumatic nebulizer of the ICP-MS instrument through PEEK-tubing. All separations were conducted at room temperature. The operation conditions of the LC-ICP-MS system are summarized in Table 1.

Total arsenic was determined using a simultaneous, inductively coupled plasma optical emission spectrometer (Spectro CIROS CCD, Spectro Analytical Instruments, Kleve, Germany) with axially viewed plasma. The selected wavelength for As and operational parameters are listed in Table 1. Instrumental conditions used were those recommended by the instrument manufacturer.

Argon with a purity of 99.996\% (White Martins-Praxair, São Paulo, SP, Brazil) was used as plasma, auxiliary, and nebulization gas.

A Multiwave 3000 microwave oven (Anton Paar, Graz, Austria) was used for sample digestion and As-species extraction.
Table 1

Instrumental conditions for total As determination by ICP OES and for As-species determination by LC-ICP-MS.

\begin{tabular}{|c|c|}
\hline \multicolumn{2}{|l|}{ Total As determination by ICP OES } \\
\hline RF power & $1500 \mathrm{~W}$ \\
\hline Plasma gas flow rate & $14 \mathrm{~L} \mathrm{~min}^{-1}$ \\
\hline Auxiliary gas flow rate & $1.0 \mathrm{~L} \mathrm{~min}^{-1}$ \\
\hline Nebulizer gas flow rate & $0.70 \mathrm{~L} \mathrm{~min}^{-1}$ \\
\hline Spray chamber & Double pass, Scott type \\
\hline Nebulizer & Cross-flow \\
\hline Plasma observation view & Axial \\
\hline Wavelength & $189.042 \mathrm{~nm}$ \\
\hline \multicolumn{2}{|l|}{ ICP-MS } \\
\hline RF power & $1400 \mathrm{~W}$ \\
\hline Plasma gas flow rate & $15 \mathrm{~L} \mathrm{~min}^{-1}$ \\
\hline Auxiliary gas flow rate & $1.2 \mathrm{~L} \mathrm{~min}^{-1}$ \\
\hline Nebulizer gas flow rate & $1.10 \mathrm{~L} \mathrm{~min}^{-1}$ \\
\hline Sampler and skimmer cones & Pt \\
\hline $\mathrm{m} / \mathrm{z}$ monitored & 75 \\
\hline Dwell time & $500 \mathrm{~ms}$ \\
\hline \multicolumn{2}{|l|}{ As speciation by LC-ICP-MS } \\
\hline Sample volume & $200 \mu \mathrm{L}$ \\
\hline Mobile phase flow rate & $1.25 \mathrm{~mL} \mathrm{~min}^{-1}$ \\
\hline Mobile phase $\mathrm{A}\left(20 \mathrm{mmol} \mathrm{L}^{-1}\right)$ & $\left(\mathrm{NH}_{4}\right)_{2} \mathrm{HPO}_{4}, \mathrm{pH} 6.0$ \\
\hline Mobile phase $\mathrm{B}\left(20 \mathrm{mmol} \mathrm{L}^{-1}\right)$ & $\left(\mathrm{NH}_{4}\right)_{2} \mathrm{CO}_{3}, \mathrm{pH} 8.5$ \\
\hline \multirow[t]{3}{*}{ LC program } & $0-1.4$ min: $30 \% \mathrm{~A}$ \\
\hline & $1.4-2.7$ min: $100 \%$ B \\
\hline & $2.7-15 \mathrm{~min} 30 \% \mathrm{~A}$ \\
\hline
\end{tabular}

Extractions of arsenic species using US were performed by means of a $20 \mathrm{kHz}$ ( $130 \mathrm{~W}$, nominal power) ultrasonic processor manufactured by Sonics and Materials, Inc. (Model VCX 130PB, Newton, CT, USA).

A centrifuge (3k30, Sigma, Osterode am Harz, Germany) was used for the extract centrifugation.

\subsection{Reagents and solutions}

Water was distilled and subsequently purified using a Milli-Q system (Millipore Corp., Billerica, MA, USA) in order to obtain resistivity of $18.2 \mathrm{M} \Omega \mathrm{cm}$. Nitric acid (Merck, Darmstadt, Germany) was purified by sub-boiling distillation (Milestone system, Model Duopur, Sorisole, Italy). Ammonium phosphate (Merck) and ammonium carbonate (Merck) solutions, both used as mobile phases, were prepared in water and then filtered through a $0.45 \mu \mathrm{m}$ membrane filter (Millipore) before use. The $\mathrm{pH}$ of the mobile phase and sample was adjusted with $1.0 \mathrm{~mol} \mathrm{~L}^{-1}$ ammonium hydroxide (Merck) or $1.0 \mathrm{~mol} \mathrm{~L}^{-1}$ nitric acid.

Stock solutions containing $1000 \mathrm{mg} \mathrm{L}^{-1}$ As in the form of dimethylarsonic acid $\left(\mathrm{C}_{2} \mathrm{H}_{6} \mathrm{AsO}_{2} \mathrm{H}\right.$, Sigma Aldrich, St. Louis, Missouri, USA), arsenite ( $\mathrm{As}(\mathrm{III})-\mathrm{NaAsO}_{2}$, Merck), arsenate ( $\mathrm{As}(\mathrm{V})-\mathrm{Na}_{2} \mathrm{HAsO}_{4} \cdot 7 \mathrm{H}_{2} \mathrm{O}$ from Riedel-de Haën, Seelze, Germany), and monomethylarsonic acid $\left(\mathrm{CH}_{5} \mathrm{AsO}_{3}\right.$, donated by Dr. J. Feldmann from the University of Aberdeen, Aberdeen, UK) were prepared in water. Stock solutions containing $1000 \mathrm{mg} \mathrm{L}^{-1}$ As of p-arsanilic acid (p-ASA, $\mathrm{C}_{6} \mathrm{H}_{8} \mathrm{AsNO}_{3}$, Sigma) and arsenobetaine $\left(\mathrm{C}_{3} \mathrm{H}_{6} \mathrm{AsCH}_{2} \mathrm{COOH}\right.$, donated by Dr. W. Goessler from Karl-Franzen University, Graz, Austria) were prepared in ammonium hydroxide (Merck). The total arsenic concentration in each stock solution was measured by ICP-MS. The standard solutions for total As determination were prepared by serial dilution of the SCP33MS (SCP Science, Baie d'Urfé, Canada) solution, which contained $10 \mathrm{mg} \mathrm{L}^{-1}$ As.

Solutions containing $10 \mathrm{mg} \mathrm{L}^{-1}$ As as $\mathrm{As}(\mathrm{III}), \mathrm{As}(\mathrm{V})$, AsB, DMA, MMA, and p-ASA were prepared in water and stored at $4{ }^{\circ} \mathrm{C}$ in a dark environment. These stock solutions were used to prepare standard solutions ranging from 0.10 to $10 \mu \mathrm{g} \mathrm{L}^{-1}$ As in water.

The CRM DORM-2 (dogfish muscle) from the National Research Council of Canada (NRCC, Ottawa, Ontario, Canada), BCR627 (tuna fish muscle) from the Institute for Reference Materials and Measurements (IRMM, Geel, Belgium), and SRM 1566b (oyster tissue) from the National Institute of Standards and Technology (NIST, Gaithersburg, MD, USA) were analyzed to evaluate the accuracy of the method. 


\subsection{Samples and sample preparation}

Samples of bivalve mollusks (Anomalocardia brasiliana sp. and Macoma constricta sp.) were collected in Todos os Santos Bay (Bahia, Brazil). After collection, the edible parts were removed from the shells with a plastic spoon, washed with ultrapure water, and transferred to polyethylene vials, which was sealed and kept at $-20{ }^{\circ} \mathrm{C}$ until the analysis was conducted. Composite samples were prepared by pooling specimens of medium size.

Before analysis, the frozen samples were thawed, homogenized in a blender, lyophilized, and ground to obtain particle sizes lower than $100 \mu \mathrm{m}$ in diameter. The lyophilized samples were placed in polyethylene flasks and kept at $4{ }^{\circ} \mathrm{C}$ in a dark environment. Speciation analysis of As was carried out in the lyophilized samples.

\subsubsection{Microwave-assisted digestion}

For total As determination, about $200 \mathrm{mg}$ of samples was accurately weighed and transferred to quartz vessels of the microwave oven and then $6 \mathrm{~mL}$ of $\mathrm{HNO}_{3}$ was added to the sample. The program was used according to the conditions recommended by the microwave oven manufacturer, which consists of (i) $10 \mathrm{~min}$ ramp to reach $1400 \mathrm{~W}$, (ii) $1400 \mathrm{~W}$ for $15 \mathrm{~min}$, and (iii) $0 \mathrm{~W}$ for $20 \mathrm{~min}$ (the cooling step). Pressure and temperature were set at 80 bar and $280{ }^{\circ} \mathrm{C}$, respectively. After cooling, the digest was transferred to a polypropylene vessels, the volume was completed to $30 \mathrm{~mL}$ with water, and the solution was stored at $4{ }^{\circ} \mathrm{C}$ until the As determination by ICP OES. The conditions used for ICP OES are summarized in Table 1.

\subsubsection{Microwave-assisted extraction}

For As-species extraction assisted by microwave energy, approximately $200 \mathrm{mg}$ of samples was accurately weighed and transferred to quartz vessels of the microwave oven, and $6 \mathrm{~mL}$ of water or a methanol-water solution $(1: 1,2: 1$, and $3: 1)$ was added to the samples. The following program was used: (i) $500 \mathrm{~W}$ for $5 \mathrm{~min}$ (ramp of $10 \mathrm{~min}$ ), (ii) $1400 \mathrm{~W}$ for $6 \mathrm{~min}$ (ramp of $10 \mathrm{~min}$ ), and (iii) $0 \mathrm{~W}$ for $20 \mathrm{~min}$ (cooling). The temperature was set at $80^{\circ} \mathrm{C}$. After cooling, the mixtures were transferred to polypropylene vessels, and the volumes were completed to $30 \mathrm{~mL}$ with water and then centrifuged at $935 \mathrm{~g}$ for $5 \mathrm{~min}$. Subsequently, the supernatants were filtered through a $0.45 \mu \mathrm{m}$ membrane syringe filter (Chromafil PTFE, Macherey-Nagel, Düren, Germany) and $200 \mu \mathrm{L}$ of the filtered extract were injected into the chromatographic column used for As-species separation. The conditions used for As speciation analysis by LC-ICP-MS are summarized in Table 1.

\subsubsection{Ultrasonic extraction}

For As-species extraction assisted by US energy, about $200 \mathrm{mg}$ of samples was accurately weighed and transferred to $50 \mathrm{~mL}$ polypropylene vessels, and $6 \mathrm{~mL}$ of water or a methanol-water solution $(1: 1,2: 1$, and $3: 1)$ was added to the sample. The mixtures were sonicated at $130 \mathrm{~W}$ for $6 \mathrm{~min}$ at an amplitude of $40 \%$. Subsequently, the volumes of the mixtures were completed to $30 \mathrm{~mL}$ with water and then treated as described above (Section 2.3.2). The conditions used for As speciation analysis by LC-ICP-MS are summarized in Table 1.

The extraction efficiencies of MAE and US were evaluated by the analysis of certified reference material analyzing CRM oyster tissues and tuna fish. A mass balance of As was calculated by comparing the sum of the concentrations of all As species and the total As concentrations determined in the extracts as well as after sample decomposition.

\subsubsection{Stability of As species submitted to microwave irradiation or sonication}

The effects of microwave and ultrasound energy on the stability of the As species were studied using the CRM oyster tissue. Approximately $200 \mathrm{mg}$ of CRM was accurately weighed and transferred to quartz vessels of the microwave oven or to $50 \mathrm{~mL}$ polypropylene flasks and spiked with As(III), As(V), AsB, DMA, MMA, and p-ASA in order to obtain final concentrations of $1.0 \mathrm{mg} \mathrm{L}^{-1}$ As. The speciation analysis of As in the spiked CRM was carried out as previously described.

\subsubsection{Total As determination by ICP OES}

Total As concentration in extracts and digested samples of bivalve mollusks and CRM were determined by ICP OES. Standard solutions ranging from 10 to $100 \mu \mathrm{g} \mathrm{L}^{-1}$ As were prepared in $5 \%(\mathrm{v} / \mathrm{v}) \mathrm{HNO}_{3}$. The instrumental conditions used for As measurements are cited in Table 1 and were adjusted to achieve the lowest limit of quantification (LOQ). The LOQ was calculated using the $10 \mathrm{~s}$ criterion, where $s$ was the standard deviation of 10 consecutive measurements of the sample blank.

\subsubsection{Arsenic speciation analysis by LC-ICP-MS}

Arsenic speciation analysis using LC-ICP-MS was carried out for CRM and bivalve mollusks. Quantification of each arsenic species was based on external calibration. Standard solutions were obtained from a multi-species solution prepared by the appropriate dilution of single-species stock solutions. The concentration range of standard solutions for each As species was 0.1 to $10 \mu \mathrm{g} \mathrm{L}{ }^{-1}$ As and were prepared in water and used to obtain the calibration curves. The instrumental conditions set for the As measurements are summarized in Table 1 and were adjusted to achieve the lowest LOQ, calculated as cited above. The chromatographic peaks of As were processed using area integration.

Possible interference by $\mathrm{Cl}\left(\mathrm{As}^{40} \mathrm{Ar}^{35} \mathrm{Cl}^{+}\right.$with $\left.\mathrm{m} / \mathrm{z} 75\right)$ was evaluated for As in the mollusk extracts, which contained $\mathrm{Cl}^{-}$. A $100 \mathrm{mg} \mathrm{L}^{-1} \mathrm{Cl}^{-}$ solution was injected in the chromatographic column and the As signal $(\mathrm{m} / \mathrm{z} 75)$ remained at the blank level. In previous studies using the same system [9], only a very small signal at $\mathrm{m} / \mathrm{z} 75$ was observed for $1000 \mathrm{mg} \mathrm{L}^{-1} \mathrm{Cl}^{-}$. Since the $\mathrm{Cl}^{-}$concentration in the mollusk extracts was lower than $200 \mathrm{mg} \mathrm{L}^{-1}$ in the final solution, it was concluded that $\mathrm{Cl}^{-}$did not interfere with As.

\section{Results and discussion}

\subsection{Total As determination}

The total As concentration found in the certified oyster tissue and tuna fish that were digested or extracted using MAE or US is shown in Table 2 .

According to the t-student test at a 95\% confidence level, recovery of total As was significantly better for MAE than US extraction. By considering only MAE, such significantly better As recovery was obtained by using pure water or a 1:1 methanol-water solution. These results accord with those found by other authors [34-38]. However, the efficiency of As-species extraction may vary from one laboratory to another. For example, in an interlaboratory study [15], the results obtained for i-As in a certified dogfish liver (DOLT-4) were spread.

\section{Table 2}

Total As recoveries from MAE and US extraction using different extractants. Results (in \%) are the average and standard deviations of three replicates of each sample. Total As determinations are by ICP OES.

\begin{tabular}{llllll}
\hline \multirow{2}{*}{ Extractants } & \multicolumn{2}{l}{ SRM 1566b } & & \multicolumn{2}{l}{ BCR 627 } \\
\cline { 2 - 3 } & MAE $^{\mathrm{a}}$ & US $^{\mathrm{b}}$ & & \multicolumn{1}{l}{ MAE $^{\mathrm{a}}$} & US $^{\mathrm{b}}$ \\
\hline Water & $99 \pm 2$ & $91 \pm 3$ & & $101 \pm 5$ & $93 \pm 2$ \\
Methanol-water (1:1) & $97 \pm 4$ & $89 \pm 5$ & & $99 \pm 7$ & $86 \pm 3$ \\
Methanol-water (2:1) & $92 \pm 2$ & $83 \pm 3$ & & $94 \pm 4$ & $81 \pm 7$ \\
Methanol-water (3:1) & $89 \pm 2$ & $77 \pm 8$ & & $91 \pm 2$ & $72 \pm 6$ \\
\hline
\end{tabular}

\footnotetext{
a MAE: microwave-assisted extraction.
}

b US: ultrasonic-assisted extraction. 
Different conditions used for sample preparations as well as different techniques used for separation and detection were possible causes of diverging results. It also was affirmed that i-As determination in such a matrix is difficult [15].

In the present study, extraction of As species by using US energy was not efficient, which could be due to the conditions used or the sample matrix. According Table 2, different results are observed for the MAE, US, and extraction mediums. More accurate results (using a $t$-test at a $95 \%$ confidence level) were obtained by using MAE and water. Therefore, these conditions were chosen for further As-species extraction.

Analyte recovery in the spiked CRM submitted to MAE and extraction using 1:1 methanol-water was evaluated. Analyte recoveries in the range of $95 \%$ to $102 \%$ were achieved. Furthermore, the total As concentration found in the digested samples was similar to that found in the sample submitted to MAE (using a $t$-test at a 95\% confidence level). In both cases, the total As concentration found agreed with the certified value.

\subsection{Extraction of arsenic species from bivalve mollusks samples}

Analyte extraction is critical in speciation analysis, mainly for solid biological tissues. Analyte losses, species interconversion, or incomplete species extraction are possible. Therefore, to achieve quantitative extraction without changing the species of the element, it is necessary to use mild extraction conditions. Even though several studies dealing with extraction procedures for arsenic species were reported [6,20-34], in the present study we investigated the use of MAE and US associated with water and mixtures of water and methanol for As-species extraction from edible tissues of mollusks. The volume of extractant and the sample mass were fixed at $6 \mathrm{~mL}$ and $200 \mathrm{mg}$, respectively. The extractant and the time of exposure to microwave radiation or sonication were then evaluated.

According to the results shown in Table 2 for total As concentration, better results were obtained when the samples were submitted to microwave radiation in water or a 1:1 water-methanol solution. These results agree with those found in previous research $[10,25,30,36,38]$. Although several extraction steps for $2 \mathrm{~min}$ at pre-defined maximum temperatures under microwave irradiation have been employed [6], in the present study only one step for $6 \mathrm{~min}$ at $80{ }^{\circ} \mathrm{C}$ was effective. In these conditions, the analyte extractions were quantitative (Table 3 ), without significant interconversion of As species. Therefore, for the subsequent tests, water (used as an extractant) and the microwave oven program described in Section 2.3.2 were used.

As mentioned before (Table 2), lower recovery of total As (using a $t$-test at a $95 \%$ confidence level) was observed when US was used for As-species extraction. Additional experiments were carried out by using a US probe to improve the extraction efficiency. However, As-species interconversion was observed. Due to this fact and the lower extraction efficiency achieved by means of sample sonication in a bath, US was not used further.

\subsection{Arsenic speciation analysis}

Arsenic species separation was conducted by using anionexchange chromatography (PRP-X100 column). Ammonium phosphate $\left(20 \mathrm{mmol} \mathrm{L}^{-1}\right)$ and ammonium carbonate $\left(20 \mathrm{mmol} \mathrm{L}^{-1}\right)$ solutions were used as mobile phases. Initial experiments were carried out using these mobile phases in isocratic or gradient elution. The influence of the $\mathrm{pH}$ of the mobile phase was evaluated, and better As-species separation was obtained by using ammonium phosphate at $\mathrm{pH} 6.0$ and ammonium carbonate at $\mathrm{pH}$ 9.0. Gradient elution was tested for both mobile phases, starting with $5 \%$ (water was used as a diluent) of a $20 \mathrm{mmol} \mathrm{L}^{-1}$ ammonium phosphate or a $20 \mathrm{mmol} \mathrm{L}^{-1}$ ammonium carbonate. The concentration of the mobile phases was increased to $100 \%$ in $25 \mathrm{~min}$.

Tests were also carried out for isocratic mode elution. In this case, $6 \mathrm{mmol} \mathrm{L}^{-1}$ ammonium phosphate at $\mathrm{pH} 6.0$ and $20 \mathrm{mmol} \mathrm{L}^{-1} \mathrm{am}-$ monium carbonate at pH 9.0 were used. Good As-species separation was observed for standards by using gradient and isocratic elutions. However, the separation of As species in oyster tissue (NIST 1566b) was not satisfactory. In this case, good separation of As species in oyster tissue and standards were achieved by using ammonium phosphate and ammonium carbonate solutions at $\mathrm{pH} 6.0$ and 9.0, respectively. To achieve better separation of As species, the elution was started using $6 \mathrm{mmol} \mathrm{L}^{-1}$ of the ammonium phosphate solution, and from 1.4 to $2.7 \mathrm{~min}$ the ammonium phosphate solution was changed to a $20 \mathrm{mmol} \mathrm{L}^{-1}$ ammonium carbonate solution. From 2.7 to $15 \mathrm{~min}$, a $6 \mathrm{mmol} \mathrm{L}^{-1}$ ammonium phosphate solution was used again. The conditions employed for LC separation are summarized in Table 1.

By using these chromatographic conditions, the retention times of $\mathrm{AsB}, \mathrm{DMA}$, and $\mathrm{As}(\mathrm{V})$ were the same for standards and certified oyster tissue. However, As(III), MMA, and p-ASA were not detected, and an unidentified As species in oyster tissue was found. As observed by

Table 3

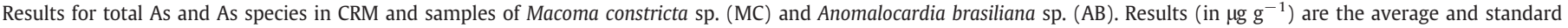
deviations of three replicates of each sample.

\begin{tabular}{|c|c|c|c|c|c|c|c|c|c|c|c|c|}
\hline \multirow[t]{2}{*}{$\begin{array}{l}\text { CRM/ } \\
\text { samples }\end{array}$} & \multicolumn{9}{|l|}{$\begin{array}{l}\text { As species } \\
\text { (LC-ICP-MS) }\end{array}$} & \multicolumn{3}{|l|}{ Total As } \\
\hline & AsB & As(III) & DMA & MMA & p-ASA & $\mathrm{As}(\mathrm{V})$ & $\mathrm{UK}_{1}$ & $\mathrm{UK}_{2}$ & $\mathrm{UK}_{3}$ & $\begin{array}{l}\sum \text { As species } \\
\text { (LC-ICP-MS) }\end{array}$ & $\begin{array}{l}\text { MAE } \\
\text { (ICP OES) }\end{array}$ & $\begin{array}{l}\text { MW } \\
\text { (ICP OES) }\end{array}$ \\
\hline DORM-2a & $16.8 \pm 0.3$ & $0.61 \pm 0.04$ & $0.841 \pm 0.003$ & $<0.001$ & $<0.001$ & $<0.003$ & - & - & - & $18.25 \pm 0.93$ & $18.75 \pm 0.66$ & $18.1 \pm 0.4$ \\
\hline $\begin{array}{l}\text { Certified } \\
\text { value }\end{array}$ & $16.4 \pm 1.1$ & - & - & - & - & - & - & - & - & - & - & - \\
\hline BCR-627 $7^{b}$ & $3.80 \pm 0.11$ & $0.29 \pm 0.04$ & $0.147 \pm 0.013$ & $0.085 \pm 0.005$ & $<0.001$ & $0.035 \pm 0.001$ & - & - & - & $4.35 \pm 0.18$ & $4.68 \pm 0.03$ & $4.56 \pm 0.04$ \\
\hline $\begin{array}{l}\text { Certified } \\
\text { Value }\end{array}$ & $3.90 \pm 0.22$ & - & $0.150 \pm 0.020$ & - & - & - & - & - & - & - & - & - \\
\hline $\begin{array}{l}\text { NIST } \\
\qquad 1566 b^{c}\end{array}$ & $5.40 \pm 0.20$ & $<0.001$ & $0.40 \pm 0.01$ & $<0.001$ & $<0.001$ & $1.16 \pm 0.01$ & $0.33 \pm 0.03$ & - & - & $7.25 \pm 0.25$ & $6.94 \pm 0.2$ & $7.2 \pm 0.3$ \\
\hline MC & $71.0 \pm 4.0$ & $16.0 \pm 1.1$ & $1.30 \pm 0.05$ & $<0.001$ & $1.07 \pm 0.01$ & $<0.003$ & $7.13 \pm 0.05$ & $3.62 \pm 0.09$ & - & $100 \pm 4$ & $99 \pm 9$ & $100 \pm 2$ \\
\hline MC & $18.2 \pm 0.7$ & $3.4 \pm 0.1$ & $<0.001$ & $<0.001$ & $2.51 \pm 0.02$ & $<0.003$ & $5.22 \pm 0.02$ & $1.80 \pm 0.05$ & - & $31.1 \pm 0.7$ & $30.0 \pm 0.4$ & $33.0 \pm 3.0$ \\
\hline $\mathrm{AB}$ & $6.4 \pm 0.4$ & $1.70 \pm 0.03$ & $<0.001$ & $1.70 \pm 0.02$ & $<0.001$ & $<0.003$ & $<0.001$ & $<0.001$ & $<0.001$ & $9.8 \pm 0.5$ & $9.8 \pm 0.7$ & $10.9 \pm 0.3$ \\
\hline$A B$ & $11.1 \pm 0.7$ & $2.81 \pm 0.02$ & $<0.001$ & $2.51 \pm 0.06$ & $<0.001$ & $<0.003$ & $<0.001$ & $<0.001$ & $<0.001$ & $16.4 \pm 0.7$ & $16.0 \pm 1.0$ & $17.1 \pm 0.8$ \\
\hline
\end{tabular}

a Certified value for total As in DORM-2: $18.0 \pm 1.1 \mu \mathrm{g} \mathrm{g}{ }^{-1}$

b Certified value for total As in BCR-627: $4.80 \pm 0.3 \mu \mathrm{g} \mathrm{g}^{-1}$

c Certified value for total As in NIST 1566b: $7.65 \pm 0.6 \mu \mathrm{g} \mathrm{g}^{-1}$. 
Nischwitz and Pergantis [39], several As species are present in the certified oyster tissue (NIST 1566b), including AsB, DMA, arsenocholine, tetramethylarsonium ion, and two arsenosugars. Probably the unidentified As species was an arsenosugar, which could not be identified in the present work. Note that $\mathrm{As}(\mathrm{III})$ and AsB elute practically at the void volume of the column, and As(III) eluted slightly earlier than AsB. This can occur because $\mathrm{As}$ (III) at $\mathrm{pH} 6.0$ is present as an uncharged species $\left(\mathrm{pKa}_{1}=9.3\right)$ and AsB ( $\left.\mathrm{pKa}=2.18\right)$ as a zwitterion.

\subsection{Arsenic species determination in mollusks}

The developed method was applied for As speciation analysis in bivalve mollusks sampled in Todos os Santos Bay (Bahia, Brazil). The chromatogram obtained from the $M$. constricta sp. sample extracted using MAE with water and M. constricta sp. sample spiked with As species at a level of $10 \mu \mathrm{g} \mathrm{L}^{-1}$ As are shown in Fig. 1. As can be observed in this figure, the retention times of As(III), AsB, DMA, and p-ASA in standard solutions and samples are the same. These results demonstrated that there were not matrix interferences. MMA and $\mathrm{As}(\mathrm{V})$ were not detected in the mollusk samples, whereas two undefined As species $\left(\mathrm{UK}_{1}\right.$ and $\mathrm{UK}_{2}$ ) were detected.

A peak of As with retention time equal to that of p-ASA is observed in Fig. 1. Probably, this peak does not correspond to p-ASA, because this species is not usually present in mollusks. It is also important that $\mathrm{As}(\mathrm{III})$, the most toxic i-As species, was present in a relatively high concentration in all mollusk samples analyzed. Sloth and Julshamn [40] reported a relatively high $\mathrm{i}$-As concentration in blue mussels (Mytilus edulis L.). However, As(III) is usually not detected in seafood, or its concentration is very low $[41,42]$. The relatively high concentration of total As (Table 3 ) found in one sample was also noteworthy.

Fig. 2 shows the chromatogram obtained for one sample of A. brasiliana sp. As(III), AsB, and MMA were detected in this sample, and only one unknown $\left(\mathrm{UK}_{3}\right)$ peak was observed. This peak also could correspond to an arsenosugar species. Arsenosugar species, such as dimethylarsinoylsugarglycol and dimethylarsinoylsugarphosphate, were identified in fish and mollusks by Nischwitz and Pergnatis [39] as well as by Schmeisser et al. [43].

The sensitivity for all As species is similar; the mean value of the slope of the calibration curves was $51.3 \pm 6.8$ counts per $\mathrm{mg} \mathrm{L}^{-1}$ As. Therefore, the unknown As species were quantified against the calibration curve of As(III). The same strategy of quantification of unknown As species has been used by Slot et al. [44] and Geng et al. [45].

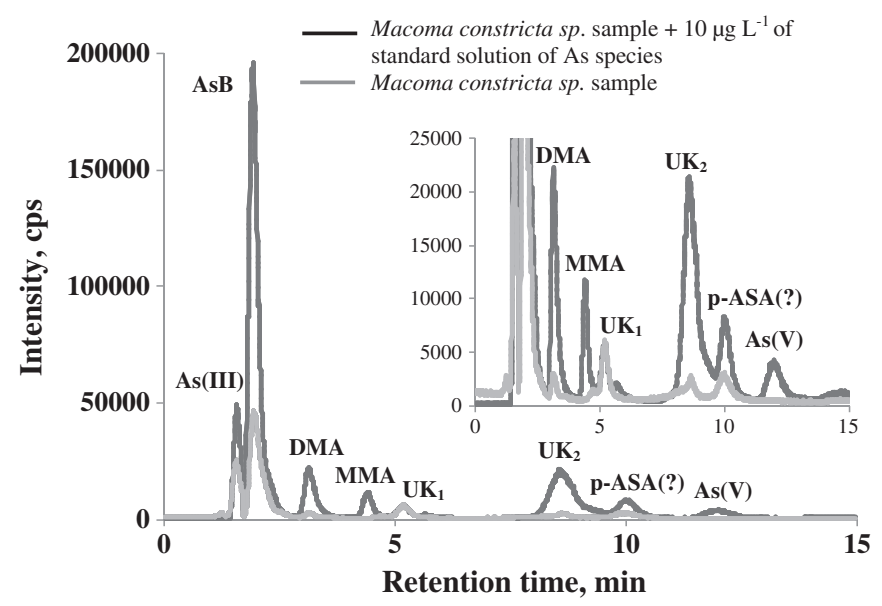

Fig. 1. LC-ICP-MS chromatograms of As species in Macoma constricta sp. after MAE with water extraction and $M$. constricta sp. spiked with a $10 \mu \mathrm{g} \mathrm{L}{ }^{-1}$ standard solution of As species. Chromatographic conditions are reported in the Experimental section.

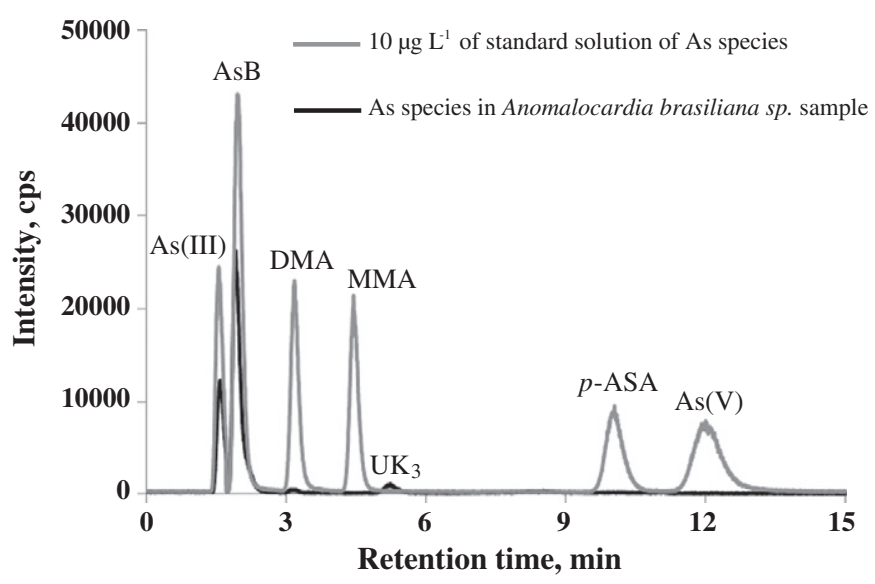

Fig. 2. LC-ICP-MS chromatograms of As species in Anomalocardia brasiliana sp. after MAE with water extraction and a $10 \mu \mathrm{g} \mathrm{L}^{-1}$ standard solution of As species. Chromatographic conditions are reported in the Experimental section.

The results for all analyzed sample tissues of bivalve mollusks and CRM are given in Table 3. As can be observed in this table, AsB was the main As species present in the samples. The concentrations of some As species were lower than their respective LOQs.

The extraction efficiency and As-species determination were evaluated by analyzing certified dogfish muscle (DORM-2), tuna fish tissue (BCR-627), and oyster tissue (SRM 1566b); the results of these evaluations are shown in Table 3. The total As in the extracts and the sum of the As-species concentrations were not different at a 95\% confidence level. This indicates that MAE and water are appropriate for As-species extraction from bivalve mollusks.

The AsB concentration determined in the CRM was in agreement with the certified values. Similar AsB concentrations were found and reported by other authors [39,42,44]. However, a higher concentration of DMA than that reported [39] was found in oyster tissue (NIST 1566b) in the present study. Higher concentrations of AsB and DMA than those reported [39] also were found in the certified oyster tissue. The difference might be due to the species quantification methods. In Table 3, it can be observed that As(III) also was detected in DORM-2.

The precision of the method was evaluated by injecting $200 \mu \mathrm{L}$ of a standard solution containing $2.5 \mathrm{ng}$ As. The coefficients of variation for five consecutive measurements were lower than $10 \%$. The LOQ was typically $0.003 \mu \mathrm{g} \mathrm{g}^{-1}$ for $\mathrm{As}(\mathrm{V})$ and $0.001 \mu \mathrm{g} \mathrm{g}^{-1}$ As for the other As species. The LOQs are of the same level as those reported for As species (Table 4). The linear correlation coefficient of the calibration curves was typically 0.999 .

\section{Conclusions}

A method for As speciation analysis in bivalve mollusks was developed using LC-ICP-MS. The extraction of As species from the samples was quantitative by using microwave energy and water as an extractant. However, US-assisted extraction led to lower analyte recovery. It was demonstrated that it is possible to separate As species in standard solutions and sample solutions by using an anion-exchange column and ammonium phosphate as well as ammonium carbonate as mobile phases.

As expected, AsB was the main As species in bivalve mollusks. Unidentified As species were detected: two in $M$. constricta sp. and one in A. brasiliana sp. A peak with the same retention time as p-ASA was detected in one sample of $M$. constricta sp., probably correspondent to an unknown As species. In this sample, the As(III) concentration was higher than in the others. 
Table 4

Limits of quantification for As-species determination by LC-ICP-MS (values in $\mu \mathrm{g} \mathrm{g}^{-1}$ ).

\begin{tabular}{|c|c|c|c|c|c|c|c|}
\hline Sample & As(III) & AsB & MMA & DMA & p-ASA & $\mathrm{As}(\mathrm{V})$ & Ref. \\
\hline Mollusks & 0.001 & 0.001 & 0.001 & 0.001 & 0.001 & 0.003 & This work \\
\hline Seafood & 0.020 & 0.020 & 0.020 & 0.020 & - & 0.020 & [11] \\
\hline Freeze-dried tissue of fish, chicken, rice, and soil & $0.0011-0.0018$ & $0.0021-0.0024$ & $0.0016-0.0054$ & $0.0017-0.0054$ & - & $0.0016-0.0045$ & [21] \\
\hline Mollusk, white fish, and cold water fish & $0.021-0.042$ & $0.043-0.086$ & $0.058-0.116$ & $0.045-0.090$ & - & $0.078-0.156$ & [46] \\
\hline Food & 0.001 & - & 0.001 & 0.002 & - & 0.002 & [47] \\
\hline Marine periwinkle & 0.250 & 0.250 & 0.250 & 0.250 & - & 0.250 & [48] \\
\hline
\end{tabular}

\section{Acknowledgments}

The authors are grateful to Conselho Nacional de Desenvolvimento Científico Tecnológico (CNPq), Fundação de Amparo à Pesquisa do Estado da Bahia (FAPESB), and Coordenação de Aperfeiçoamento de Pessoal de Nível Superior (CAPES) for their financial support.

\section{References}

[1] C.L.C. Manso, O.F.S. Alves, L.R. Martins, Echinodermata da Baía de Todos os Santos e a Baía de Aratu (Bahia, Brasil), Biota Neotrop. 3 (2008) 179-196.

[2] J.M. Neff, Ecotoxicology arsenic in the marine environment, Environ. Toxicol. Chem. 5 (1997) 917-927.

[3] C. Sörös, E.T. Bodó, P. Fodor, R. Morabito, The potential of arsenic speciation in mollusks for environmental monitoring Anal. Bioanal. Chem. 377 (2003) 25-31.

[4] E. Sabbioni, M. Fischbach, G. Pozzi, R. Pietra, M. Gallorini, J.L. Piette, Cellular retention, toxicity and carcinogenic potential of seafood arsenic. I. Lack of cytotoxicity and transforming activity of arsenobetaine in the BALB/3T3 cell line, Carcinogenesis 12 (1991) 1287-1291.

[5] M.A. Adams, P.M. Bolger, E.L. Gunderson, Arsenic exposure and health, in: W.R. Chappell, C.O. Abernathy, C.R. Cothern (Eds.), Special Issue of "Environmental Geochemistry and Health", Science and Technology Letters, Northwood, UK, 1995, p. 41.

[6] K.L. Ackley, C. B'Hymer, K.L. Sutton, J.A. Caruso, Speciation of arsenic in fish tissue using microwave-assisted extraction followed by HPLC-ICP-MS, J. Anal. At. Spectrom. 14 (1999) 845-850.

[7] U. Kohlmeyer, E. Jantzen, J. Kuballa, S. Jakubik, Benefits of high resolution IC-ICP-MS for the routine analysis of inorganic and organic arsenic species in food products of marine and terrestrial origin, Anal. Bioanal. Chem. 377 (2003) 6-13.

[8] Á.H. Pétursdóttir, H. Gunnlaugsdóttir, H. Jörundsdóttir, A. Raab, E.M. Krupp, J. Feldmann, Determination of inorganic arsenic in seafood: Emphasizing the need for certified reference materials, Pure Appl. Chem. 84 (2012) 191-202.

[9] F.A. Duarte, J.S.F. Pereira, M.F. Mesko, F. Goldschmidt, E.M.M. Flores, V.L. Dressler, Evaluation of liquid chromatography inductively coupled plasma mass spectrometry for arsenic speciation in water from industrial treatment of shale, Spectrochim. Acta B 62 (2007) 978-984.

[10] C. B'Hymer, J.A. Caruso, Arsenic and its speciation analysis using high-performance liquid chromatography and inductively coupled plasma mass spectrometry, J. Chromatogr. A 1045 (2004) 1-13.

[11] A. Leufroy, L. Noël, V. Dufailly, D. Beauchemin, T. Guérin, Determination of seven arsenic species in seafood by ion exchange chromatography coupled to inductively coupled plasma-mass spectrometry following microwave assisted extraction: Method validation and occurrence data, Talanta 83 (2011) 770-779.

[12] J. Zheng, W. Goessler, W. Kosmus, Speciation of arsenic compounds by coupling high-performance liquid chromatography with inductively coupled plasma mass spectrometry, Microchim. Acta 130 (1998) 71-79.

[13] E. Schmeisser, W. Goessler, N. Kienzl, K.A. Francesconi, Arsenosugars do form volatile analytes: determination by HPLC-HG-ICPMS and implications for arsenic speciation analyses, Anal. Chem. 76 (2004) 418-423.

[14] M.J. Mato-Fernández, J.R. Otero-Rey, J. Moreda-Piñeiro, E. Alonso-Rodríguez, P. López-Mahía, S. Muniategui-Lorenzo, D. Prada-Rodríguez, Arsenic extraction in marine biological materials using pressurised liquid extraction, Talanta 71 (2007) 515-520.

[15] I. Baer, M. Baxter, V. Devesa, D. Vélez, G. Raber, R. Rubio, T. Llorente-Mirandes, J.J. Sloth, P. Robouch, B. de la Calle, Performance of laboratories in speciation analysis in seafood - case of methylmercury and inorganic arsenic, Food Control 22 (2011) 1928-1934.

[16] R. Rubio, M.J. Ruiz-Chancho, J.F. López-Sánchez, Sample pre-treatment and extraction methods that are crucial to arsenic speciation in algae and aquatic plants, Trends Anal. Chem. 29 (2010) 53-69.

[17] P.A. Gallagher, S. Murray, X. Wei, C.A. Schwegel, J.T. Creed, An evaluation of sample dispersion media used with accelerated solvent extraction for the extraction and recovery of arsenicals from LFB and DORM-2, J. Anal. At. Spectrom. 17 (2002) $581-586$.

[18] J.W. McKiernan, J.T. Creed, C.A. Brockhoff, J.A. Caruso, R.M. Lorenzana, A comparison of automated and traditional methods for the extraction of arsenicals from fish, J. Anal. At. Spectrom. 14 (1999) 607-613.
[19] U. Kohlmeyer, J. Kuballa, E. Jantzen, Simultaneous separation of 17 inorganic and organic arsenic compounds in marine biota by means of high-performance liquid chromatography/inductively coupled plasma mass spectrometry, Rapid Commun. Mass Spectrom. 16 (2002) 965-974.

[20] M. Ochsenkühn-Petropulu, J. Varsamis, G. Parissakis, Speciation of arsenobetaine in marine organisms using a selective leaching/digestion procedure and hydride generation atomic absorption spectrometry, Anal. Chim. Acta 337 (1997) 323-327.

[21] I. Pizarro, M. Gómez, C. Cámara, M.A. Palacios, Arsenic speciation in environmental and biological samples: extraction and stability studies, Anal. Chim. Acta 495 (2003) 85-98.

[22] A. Moreda-Pineiro, J. Moreda-Pineiro, P. Herbello-Hermelo, P. Bermejo-Barrera, S. Muniategui-Lorenzo, P. Lopez-Mahia, D. Prada-Rodriguez, Application of fast ultrasound water-bath assisted enzymatic hydrolysis - high performance liquid chromatography-inductively coupled plasma-mass spectrometry procedures for arsenic speciation in seafood materials, J. Chromatogr. A 1218 (2011) 6970-6980.

[23] V. Dufailly, M. Nicolas, J. Richoz-Payot, E. Poitevin, Validation of a method for arsenic speciation in food by ion chromatography-inductively coupled plasma/mass spectrometry after ultrasonic-assisted enzymatic extraction, J. AOAC Int. 94 (2011) 947-958.

[24] R. Tukai, W.A. Maher, I.J. McNaught, M.J. Ellwood, Measurement of arsenic species in marine macroalgae by microwave-assisted extraction and high performance liquid chromatography-inductively coupled plasma mass spectrometry, Anal. Chim. Acta 457 (2002) 173-185.

[25] S. Foster, W. Maher, F. Krikowa, S. Apte, A microwave-assisted sequential extraction of water and dilute acid soluble arsenic species from marine plant and animal tissues, Talanta 71 (2007) 537-549.

[26] G. Salgado, M.A. Quijano, M.M. Bonilla, Determination of soluble toxic arsenic species in alga samples by microwave-assisted extraction and high performance liquid chromatography-hydride generation-inductively coupled plasma-atomic emission spectrometry, J. Chromatogr. A 1129 (2006) 54-60.

[27] V. Dufailly, L. Noël, J.-M. Frémy, D. Beauchemin, T. Guérin, Optimisation by experimental design of an IEC/ICP-MS speciation method for arsenic in seafood following microwave assisted extraction, J. Anal. At. Spectrom. 22 (2007) 1168-1173.

[28] G. Salgado, M.A. Quijano, M.M. Bonilla, Assessment of total arsenic and arsenic species stability in alga samples and their aqueous extracts, Talanta 75 (2008) 897-903.

[29] C. Han, X. Cao, J.-J. Yu, X.-R. Wang, Y. Shen, Arsenic speciation in Sargassum fusiforme by microwave-assisted extraction and LC-ICP-MS, Chromatographia 69 (2009) 587-591.

[30] J. Kirby, W. Maher, Measurement of arsenic species in freeze-dried marine animal tissues by microwave-assisted extraction and HPLC-ICP-MS, J. Anal. At. Spectrom. 17 (2002) 838-843.

[31] E. Alonso-Rodríguez, J. Moreda-Piñeiro, P. López-Mahía, D. Prada-Rodríguez, E. Fernández-Fernández, S. Muniategui-Lorenzo, A. Moreda-Piñeiro, A. BermejoBarrera, P. Bermejo-Barrera, Pressurized liquid extraction of organometals and its feasibility for total metal extraction, Trends Anal. Chem. 25 (2006) 511-519.

[32] P.A. Gallagher, J.A. Shoemaker, X. Wei, C.A. Brockhoff-Schwegel, J.T. Creed, Extraction and detection of arsenicals in seaweed via accelerated solvent extraction with ion chromatographic separation and ICP-MS detection, Fresenius J. Anal. Chem. 369 (2001) 71-80

[33] A. Moreda-Piñeiro, M.C. Barciela-Alonso, R. Domínguez-González, E. Peña-Vázquez, P. Herbello-Hermelo, P. Bermejo-Barrera, Alternative solid sample pretreatment methods in green analytical atomic spectrometry, Spectrosc. Lett. 42 (2009) 394-417.

[34] J.A. Brisbin, J.A. Caruso, Comparison of extraction procedures for the determination of arsenic and other elements in lobster tissue by inductively coupled plasma mass spectrometry, Analyst 127 (2002) 921-929.

[35] R.Y. Wang, Y.L. Hsu, L.F. Chang, S.J. Jiang, Speciation analysis of arsenic and selenium compounds in environmental and biological samples by ion chromatographyinductively coupled plasma dynamic reaction cell mass spectrometer, Anal. Chim. Acta 590 (2007) 239-244.

[36] S. Hirata, H. Toshimitsu, M. Aihara, Determination of arsenic species in marine samples by HPLC-ICP-MS, Anal. Sci. 22 (2006) 39-43.

[37] S. Karthikeyan, S. Hirata, C.S.P. Iyer, Determination of arsenic species by microwaveassisted extraction followed by ion-pair chromatography-ICPMS: analysis of reference materials and fish tissues, Int. J. Environ. Anal. Chem. 84 (2004) 573-582.

[38] S. Karthikeyan, S. Hirata, Ion chromatography-inductively coupled plasma mass spectrometry determination of arsenic species in marine samples, Appl. Organomet. Chem. 18 (2004) 323-330.

[39] V. Nischwittz, S.A. Pergantis, Liquid chromatography online with selected reaction monitoring electrospray mass spectrometry for the determination of organoarsenic 
species in crude extracts of marine reference materials, Anal. Chem. 77 (2005) 5551-5563.

[40] J.J. Sloth, K. Julshamn, Survey of total and inorganic arsenic content in blue mussels (Mytilus edulis L.) from Norwegian fiords: revelation of unusual high levels of inorganic arsenic, J. Agric. Food Chem. 56 (2008) 1269-1273.

[41] A. Ruttens, A.C. Blanpain, L. de Temmerman, N. Waegeneers, Arsenic speciation in food in Belgium. Part 1: fish, molluscs and crustaceans, J. Geochem. Explor. 121 (2012) 55-61.

[42] R. Wahlen, S. McSheehy, C. Scriver, Z. Mester, Arsenic speciation in marine certified reference materials. Part 2. The quantification of water-soluble arsenic species by high-performance liquid chromatography-inductively coupled plasma mass spectrometry, J. Anal. At. Spectrom. 19 (2004) 876-882.

[43] E. Schmeisser, R. Raml, K.A. Francesconi, D. Kuehnelt, A.L. Lindberg, C. Sörösc, W. Goessler, Thio arsenosugars identified as natural constituents of mussels by liquid chromatography-mass spectrometry, Chem. Commun. 16 (2004) 1824-1825.

[44] J.J. Sloth, E.H. Larsen, K. Julshamn, Determination of organoarsenic species in marine samples using gradient elution cation exchange HPLC-ICP-MS, J. Anal. At. Spectrom. 18 (2003) 452-459.
[45] W. Geng, R. Komine, T. Ohta, T. Nakajima, H. Takanashi, A. Ohki, Arsenic speciation in marine product samples: comparison of extraction-HPLC method and digestioncryogenic trap method, Talanta 79 (2009) 369-375.

[46] J. Moreda-Piñeiro, E. Alonso-Rodríguez, V. Romarís-Hortas, A. Moreda-Piñeiro, P. López-Mahía, S. Muniategui-Lorenzo, D. Prada-Rodríguez, P. Bermejo-Barrera, Assessment of the bioavailability of toxic and non-toxic arsenic species in seafood samples, Food Chem. 130 (2012) 552-560.

[47] R.A. Schoof, L.J. Yost, J. Eickhoff, E.A. Crecelius, D.W. Cragin, D.M. Meacher, D.B. Menzel, A market basket survey of inorganic arsenic in food, Food Chem. Toxicol. 37 (1999) 839-846.

[48] K.J. Whaley-Martin, I. Koch, K.J. Reimer, Arsenic species extraction of biological marine samples (Periwinkles, Littorina littorea) from a highly contaminated site, Talanta 88 (2012) 187-192. 